\title{
CENPS Gene
}

National Cancer Institute

\section{Source}

National Cancer Institute. CENPS Gene. NCI Thesaurus. Code C116620.

This gene is involved in DNA binding and repair. 